PERM JOURNAL OF PETROLEUM AND MINING ENGINEERING

ВЕСТНИК ПНИПУ. ГЕОЛОГИЯ. НЕФТЕТАЗОВОЕ И ГОРНОЕ ДЕЛО

ISSN 2224-9923

Volume / Том 20 №1 2020

http://vestnik.pstu.ru/g

UDC 622.276:552.578.2.061.4

Article / Статья

(C) PNRPU / ПНИПУ, 2020

\title{
LABORATORY SIMULATION OF CHANGE IN MECHANICAL AND FLOW PROPERTIES OF RESERVOIR FORMATIONS AT VARIOUS STAGES OF OIL-FIELD DEVELOPMENT
}

\section{Daniil A. Karmanskiy, Dmitriy G. Petrakov}

Saint Petersburg Mining University (2 21 $1^{\text {st }}$ Line, Vasilyevsky island, Saint Petersburg, 199106, Russian Federation)

\section{ЛАБОРАТОРНОЕ МОДЕЛИРОВАНИЕ ИЗМЕНЕНИЯ МЕХАНИЧЕСКИХ И ФИЛЬТРАЦИОННЫХ СВОЙСТВ ПОРОД КОЛЛЕКТОРОВ НА РАЗЛИЧНЫХ ЭТАПАХ РАЗРАБОТКИ МЕСТОРОЖДЕНИЙ НЕФТИ}

\author{
Д.А. Карманский, Д.Г. Петраков \\ Санкт-Петербургский горный университет (199106, Россия, г. Санкт-Петербург, Васильевский остров, 21-я линия, 2)
}

Received / Получена: 02.10.2019. Accepted / Принята: 10.01.2020. Published / Опубликована: 02.03.2020

\section{Key words:}

effective pressure, reservoir

pressure, rock pressure, porosity, permeability, saturation, watercut deformations, strength properties, elastic properties, poroelasticity, uniaxial compression.
At different stages of oil and gas field development, a reservoir undergoes various stress-strain states. The change of reservoir pressure during development results in the change in physical and mechanical properties of the reservoir. In terms of geochemistry, the fluids also affect the properties of the host rocks. The process of reservoir fluid extraction can clog flow channels with washed-out rock particles and deposited paraffins and salts, but also decrease the strength and elastic characteristics of the rock.

The article provides a brief analysis of operations affecting the causes of changes in the physical, mechanical, porosity and permeability properties of formations during drilling and oil-field development. The method of theoretical calculation of changes in the formations' porosity and permeability is provided.

To establish the convergence of theoretical calculation methods with real data, the tests to determine the uniaxial compressive strength and the filtration experiments on terrigenous samples of a West Siberian field were carried out. Water and kerosene in different proportions were used as saturating fluids in the experiment to determine physical and mechanical properties. Based on the data obtained, the dependencies of the modulus of elasticity and the uniaxial compressive strength on different types of saturation were derived, with diagrams and calculating formulas given. In the filtration experiment, the influence of effective pressure on permeability of samples at volumetric compression was determined. The dependencies of permeability decline on the sample axial load were established.

The obtained dependencies can be used to work out geological and engineering procedures for well stimulation and field development management during the entire operational life cycle.

На различных этапах разработки нефтяных и газовых месторождений пласт испытывает различные напряженнодеформированные состояния. Изменение пластового давления в процессе разработки приводит к смене физикомеханических свойств пласта. С точки зрения геохимии, на свойства вмещающих пород также оказывают влияние сами флюиды. Процесс извлечения пластовой жидкости может вызывать не только закупоривание фильтрационных каналов вымываемыми частицами породы и выпадением парафинов и солей, но и уменьшение прочностных и упругих характеристик породы.

В статье приведен краткий анализ работ, затрагивающих причины изменения физико-механических и фильтрационно-емкостных свойств пластов в процессе бурения и разработки месторождений нефти. Приведена методика теоретического расчета изменений пористости и проницаемости пластов.

Для установления сходимости теоретических методов расчета с реальными данными были проведены испытания по определению предела прочности при одноосном сжатии и фильтрационные эксперименты на терригенных образцах одного из месторождений Западной Сибири. В эксперименте по определению физико-механических свойств в качестве жидкостей насыщения использовались вода и керосин в различном соотношении. На основе полученных данных были выведены зависимости модуля упругости и предела прочности при одноосном сжатии от различного вида насыщенности, приведены графики и расчетные формулы. В фильтрационном эксперименте при объемном сжатии определялось влияние эффективного давления на проницаемость образцов. Установлены зависимости уменьшения проницаемости от осевой нагрузки на образец.

Полученные зависимости можно использовать при подготовке геолого-технических мероприятий по интенсификации притока и при управлении разработкой месторождения на протяжении всего жизненного цикла.

Daniil A. Karmanskiy (Author ID in Scopus: 57209507897) - Engineer of the Laboratory Physical and Mechanical Properties and Rock Facture (tel.: +007 921865 20 64, e-mail: karmanskiy.da@yandex.ru). The contact person for correspondance.

Dmitriy G. Petrakov (Author ID in Scopus: 57015158900) - PhD in Engineering, Head of Oil and Gas Department (tel.: +007 921788 19 62, e-mail: petrakovdg@mail.ru).

Карманский Даниил Александрович - инженер лаборатории физико-механических свойств и разрушения горных пород (тел.: +007921 8652064 , e-mail: karmanskiy.da@yandex.ru). Контактное лицо для переписки.

Петраков Дмитрий Геннадьевич - кандидат технических наук, декан нефтегазового факультета (тел.: +007 921 788 19 62, e-mail: petrakovdg@mail.ru). 


\section{Introduction}

The equilibrium state of rocks, which has established over geological time, undergoes changes starting from the exploration and development stage (Fig. 1). At each stage of development, different physical (variation/maintenance of reservoir pressure, perforation, hydraulic fracturing, etc.) and chemical (application of chemical methods to enhance oil recovery, etc.) factors have a certain effect on the reservoir's porosity, permeability and physicalmechanical properties [1-2].

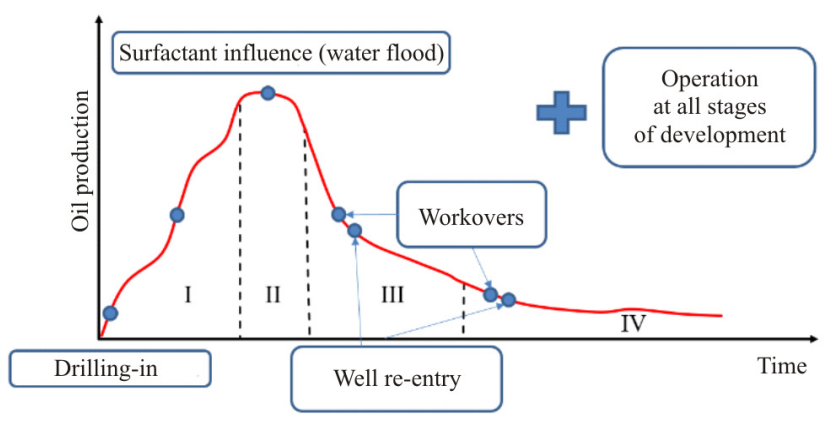

Fig. 1. Main stages of field development

Surfactant influence during well-drilling was determined in order to increase the drilling rate and reduce pressure at hydraulic fracturing [3-9]. However, due to the complexity of processes occurring in the formation, there is often little effect of reducing the strength of rocks from the application of surfactant solutions in practice [10-11]. In the research works [12-13], the change in rock properties is associated with the chemical composition, dielectric permeability and electrical conductivity of saturating fluids. Mineralization of water used in reservoir pressure maintenance system can influence rock permeability [14-18]. The influence of effective pressure on pore compressibility and change in permeability is studied in detail in [19-31].

To improve the accuracy of development engineering it is recommended to use all available data on the field and reservoir, as well as to constantly monitor their changes over time.

\section{Porosity and Permeability of Formation as a Function of Reservoir Pressure}

The main component of the stress state is formed by the weight of the overlying strata, and it almost never changes during field development. Provided there is a connection between the formation and surface waters, the pressure in the formation will correspond to the hydrostatic head pressure of exposed fluid. Where during pool formation the reservoir fluid had no possibility to reflux, such a reservoir will have abnormally high pressure. In both cases, optimum reservoir pressure should be maintained in order to prevent irreversible reservoir deformations that will result in significant reduction in porosity and permeability and sharp drop in flow rates.

The study [19] describes the procedure for calculating the change in permeability and porosity by the loading method while maintaining the constant pore pressure. The deformation at uniaxial compression at drainage is measured by the formula:

$$
e=e_{11}=\frac{\sigma_{11}^{f}-\left(1-m_{0}\right) \beta_{1} K p_{0}}{\left(1-m_{0}\right)\left(\lambda_{1}+2 \lambda_{2}\right)}=-\frac{B}{1-m_{0}} p_{e f}
$$

where $\sigma_{11}^{f}$ is fictitious stress, MPa; $m_{0}$ is porosity, unit fraction; $\beta_{0} K, \beta_{1} K$ is porous medium cementation; $p_{0}$ is reservoir pressure, $\mathrm{MPa} ; p_{e f}$ is effective pressure, $\mathrm{MPa} ; B=\frac{1}{\lambda_{1}+2 \lambda_{2}}$, where $\lambda_{1}, \lambda_{2}$ are the first and second Lamé parameters, respectively.

The ratio $\varepsilon=\beta_{1} K$ is called mechanical characteristic of rock formation, a criterion of the degree of soil compaction or of rock cementation. The closer the cementation index $\varepsilon$ is to unity, the harder is the particle repack, and the harder they are bound to each other [19].

The effective pressure is determined by the formula:

$$
\begin{aligned}
& p_{e f}=-\sigma_{11}^{f}+\left(1-m_{0}\right) \beta_{0} K p_{0}= \\
& =q-\left(1-m_{0}\right) \beta_{1} K p_{0}=q-n p_{0},
\end{aligned}
$$

where $q$ is the full load applied, MPa.

The authors [32] claim that due to small capillary pressure values, its effect on the effective pressure is negligible.

The coefficient $n=\left(1-m_{0}\right) \beta_{1} K$ shows what share of pore pressure should be taken into 
account. In the article, the value $n=0.8$ was used for the calculations, which corresponds to the calculated cementation factor value $\varepsilon=\beta_{1} K=0,2-0,3[19,33-43]$.

The relation between the porosity increment $\Delta m$, the sample volumetric deformation $\Delta e$ and the pore pressure increase increment [19] is established from the equations of continuity and generalized Hooke's law [19]:

$$
\Delta m=\left(1-m_{0}\right)\left(1-\beta_{1} K\right)\left(\Delta e+\beta_{1} \Delta p\right) .
$$

Compressibility coefficients of pores, medium and skeleton of the rock are determined by the formulas [19]:

$$
\begin{gathered}
\beta_{\text {п }}=\left(\frac{1}{v_{\text {пор }}}\right) \frac{\Delta v_{\text {пор }}}{\Delta p_{*}}=\frac{\beta_{\mathrm{c}}}{m_{0}}, \\
\beta_{\mathrm{c}}=\frac{\Delta m}{\Delta p_{*}}=\frac{1}{v_{0}} \frac{\Delta v_{\text {пор }}}{\Delta p_{*}}, \\
\beta_{\text {тв }}=\frac{\Delta e}{\Delta p_{*}}=\frac{1}{v_{0}} \frac{\Delta v}{\Delta p_{*}},
\end{gathered}
$$

where $\beta_{\text {пा }}$ is compressibility of pores, $\mathrm{MPa}^{-1} ; \beta_{\mathrm{c}}$ is compressibility of medium, $\mathrm{MPa}^{-1} ; v_{0}$ is compressibility of rock skeleton, $\mathrm{MPa}^{-1} ; v_{0}$ is initial volume of sample; $\Delta v$ is change of its full volume; $\Delta v_{\text {пор }}$ is change of pore volume; $\Delta p *$ is recorded (simultaneously with pore pressure) value of applied load (effective pressure), MPa.

The diagram of porosity dependency on effective pressure is described with high accuracy by the exponential relation [19]:

$$
m=m_{0} \exp \left[a_{m}\left(p^{f}-p_{0}^{f}\right)\right],
$$

where $m$ is the porosity coefficient at pressure $p^{f}$; $m_{0}$ is the porosity coefficient at initial pressure $p_{0}^{f}$; $a_{m} \approx \beta_{\text {п }}$ is the pore compressibility coefficient, $\mathrm{MPa}^{-1}$.

Permeability is calculated as a function of porous medium:

$$
k=k_{0}\left(\frac{m}{m_{0}}\right)^{a_{k} / a_{m}},
$$

where $k, m$ is permeability and porosity at effective pressure; $a_{k}, a_{m}$ are coefficients of change in permeability and compressibility of pores, respectively, $\mathrm{MPa}^{-1}, a_{k} / a_{m} \approx 10$ for sandy rocks.

\section{Results of Experimental Studies}

To determine the effect of rock saturation on the properties of terrigenous rocks, the strength and elastic characteristics were studied [44-46]. Rocks (mainly sandstone) from West Siberian deposits, occurring at a depth of approx. 1,800 m, were used as the sample material.

Figure 2 shows the results of determining the uniaxial compressive strength and modulus of elasticity. Following the study results, no dependency between water saturation of the sample and the Poisson's ratio was determined. The following designations were adopted: group 0 - airdried samples; group 1 - samples fully saturated with kerosene; group 2 - samples saturated with $25 \%$ water and $75 \%$ kerosene; group 3 - samples saturated with $50 \%$ water and $50 \%$ kerosene; group 4 - samples saturated with $75 \%$ water and $25 \%$ kerosene; and group 5 - samples fully saturated with water.

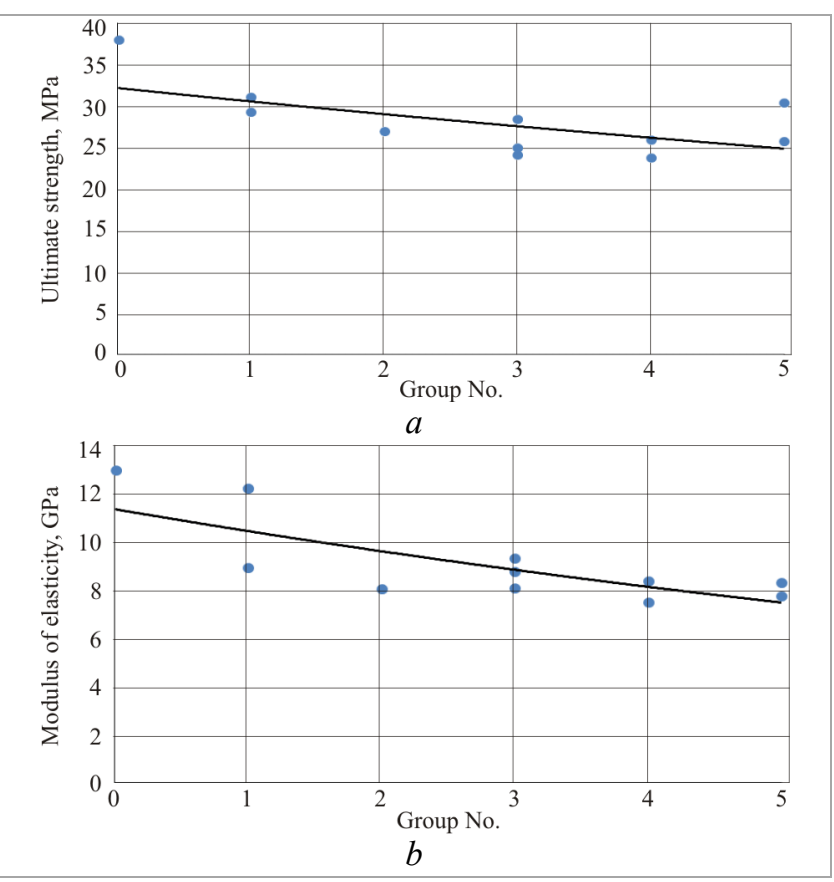

Fig. 2. Dependency of ultimate strength $(a)$ and modulus of elasticity $(b)$ on the type of saturating fluid

The indicated groups can be related to the stages of development: groups 1 and 2 can be referred to the 
stages of well bringing-in and production build-up in the field; group 3 corresponds to the stage of consistently high level of production; and group 4 and 5 denote the stages of production decline and watercut increase in the well production.

The dependency of the rock sample modulus of elasticity $E, \mathrm{GPa}$, on fluid saturation can be represented as follows:

$$
E=9,8127 \exp (-0,002 \cdot S w)
$$

where $S w$ is water saturation, unit fraction.

The flow experiment (Fig. 3, $a, b$ ) was carried out at a confining pressure of $40 \mathrm{MPa}$, which corresponds to the rock pressure at a depth of $1,800 \mathrm{~m}$. Lowmineralized water was pumped through the watersaturated sample with constant flow until the pore pressure level-off. After that, the axial load applied on the sample was increased in stages: the first stage of loading was $2 \mathrm{kN}$, followed by the increase from 10 to $50 \mathrm{kN}$ in increments of $10 \mathrm{kN}$, six stages in total (see Fig. 3, a). After testing, the sample was broken down to determine the ultimate strength [47-49].

The core sample permeability coefficient $k, \mathrm{~m}^{2}$ $\left(1\right.$ Darcy $\left.=1.02 \cdot 10^{-12} \mathrm{~m}^{2}\right)$, was calculated using Darcy's law

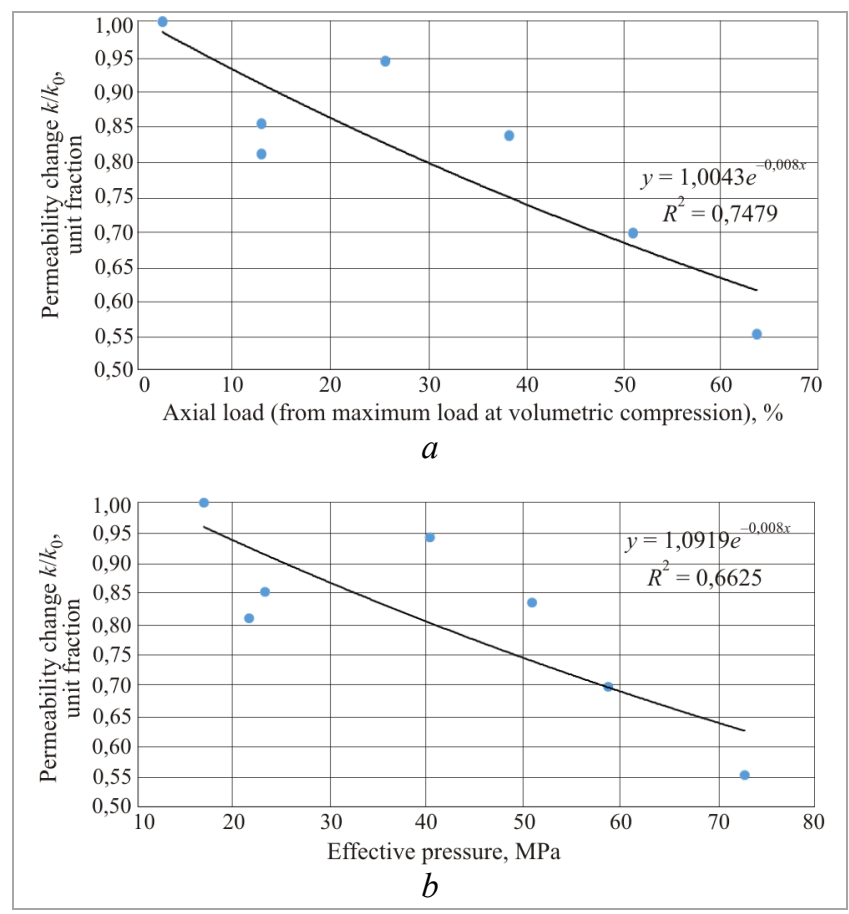

Fig. 3. Permeability change dependency on the axial load at volumetric compression $(a)$ and on effective pressure $(b)$

$$
k=\frac{\mu \cdot L \cdot Q}{S \cdot \Delta P},
$$

where $\mu$ is dynamic viscosity of fluid, $\mathrm{Pa} \cdot \mathrm{s} ; L$ is length of the core sample, $\mathrm{m}$; $Q$ is a given rate of fluid flow through the core sample, $\mathrm{m}^{3} / \mathrm{s} ; S$ is the cross-sectional area of the core sample, $\mathrm{m}^{2}$; $\Delta P$ is pressure drop at the core sample edges at the given flow rate, $\mathrm{Pa}$.

The effective pressure for each stage was determined by the formula:

$$
p_{\text {ef }}=p_{\text {rock }}+p_{\text {vert }}-p_{\text {por }}
$$

where $p_{\text {rock }}$ is confining pressure, $\mathrm{MPa} ; p_{\text {vert }}$ is axial pressure applied, $\mathrm{MPa} ; p_{\text {por }}$ is pore pressure in the sample, MPa.

The permeability change coefficient was calculated from the expression:

$$
\Delta k=\frac{k_{i}}{k_{0}},
$$

where $k_{i}$ is the permeability coefficient of the $i$-th stage; and $k_{0}$ is the permeability coefficient of the first stage, $\mathrm{mD}$.

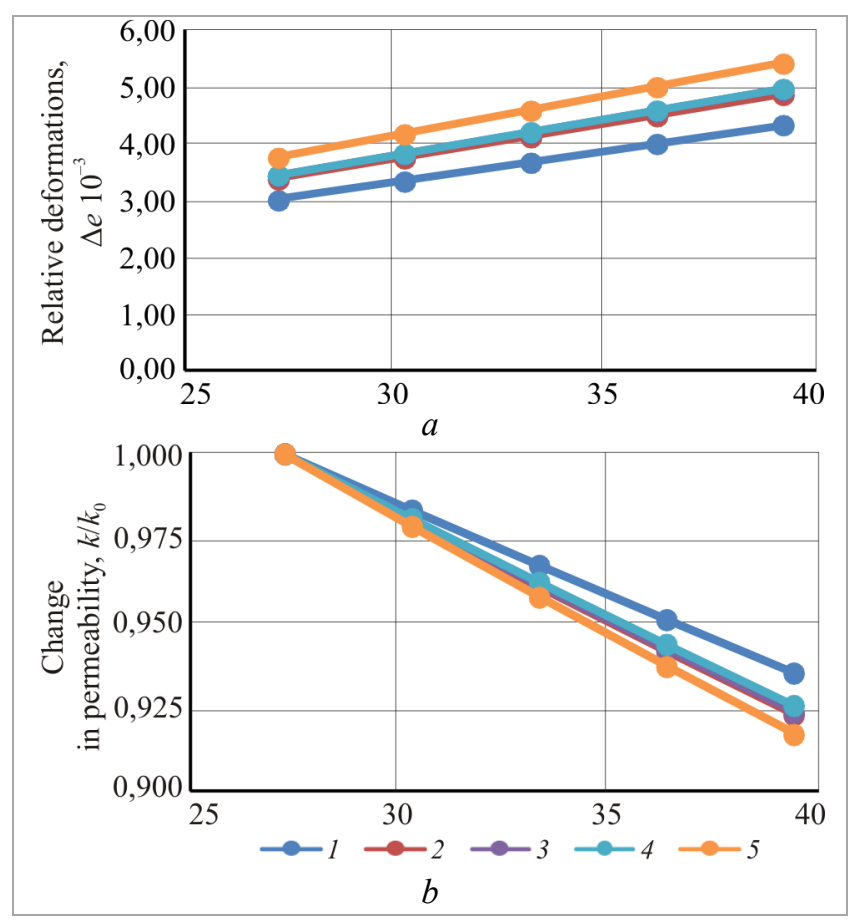

Fig. 4. Dependency of relative deformations $(a)$ and change in permeability $(b)$ on saturation and effective pressure 
Figure $3, b$ presents the dependency of the change in permeability on effective pressure. With the increase of effective pressure on the sample from 20 to $40 \mathrm{MPa}$, a $20 \%$ decrease in permeability is observed. At the effective pressure of $60 \mathrm{MPa}$, the permeability decrease is approx. $30 \%$ from the initial value, and the process is gradually reduced.

\section{Results of Theoretical Studies}

Using the experimental elasticity modulus dependency on water saturation, changes in relative deformation and permeability were calculated.

Fig. 4 (a) shows the dependency of reservoir relative deformations on saturation and effective pressure.

With the growth of water content in the reservoir, relative deformations increase, i.e. the rock becomes more plastic, while the uniaxial compressive strength decreases. The prevalence of plastic deformations causes irreversible compression of the reservoir and results in decrease in the elastic strength of the rock. The relative deformation increment at the effective pressure increase is higher in water-saturated samples, which is also due to an increase in plasticity in the presence of water. Fig. $4(b)$ presents the dependency of permeability change on saturation and effective pressure. The largest decrease in permeability is observed at a significant decline in formation pressure and increase in watercut (line 5).
It should be noted that the results obtained experimentally and computationally are reproducible. The calculated decrease in permeability with an increase in effective pressure from 30 to $40 \mathrm{MPa}$ is $6.67 \%$ for fully water-saturated rock. A laboratory experiment with an identical sample retrieved a value of $6.6 \%$ at an increase of effective pressure in the same range.

\section{Conclusion}

The results of theoretical and experimental research prove the necessity of studying the properties of rocks in various saturated states.

The type of saturating fluid determines strain, strength and elastic properties, as well as changes in porosity and permeability.

The decrease in strength of rocks and the prevalence of plastic deformations occur with the formation pressure decline, and also due to gradual increase in watercut. All of these can affect the projected outcome of mining engineering operations to enhance production.

The method used to estimate the change in permeability has produced the result similar to the experimental data. Nonetheless, it should be noted that since the studies were conducted for hydrophilic reservoirs, similar studies should be performed for hydrophobic rocks.

\section{References}

1. Kolchitskaia T.N., Mikhailov N.N. Vliianie tsiklicheskikh rezhimov ekspluatatsii skvazhin na izmenenie sostoianiia neftegazovykh plastov [The influence of cyclic modes of well operation on the state of oil and gas reservoirs]. Geology, Geophysics and Development of Oil and Gas Fields, 2002 no.5, pp.78-81.

2. Ban A. et al. Vliianie svoistv gornykh porod na dvizhenie $\mathrm{v}$ nikh zhidkosti [The influence of rock properties on the movement of fluid in them]. Moscow, Gostoptekhizdat, 1962, pp.158-187.

3. Rebinder P.A. Poverkhnostnye iavleniia $v$ dispersnykh sistemakh. fiziko-khimicheskaia mekhanika [Surface phenomena in dispersed systems. Physicochemical Mechanics]. Izbrannye trudy. Moscow, Nauka, 1979, 384 p.
4. Rebinder P.A., Shreiner L.A. Fizikokhimicheskii metod uskoreniia bureniia tverdykh porod $\mathrm{s}$ pomoshchiu dobavok, ponizitelei tverdosti $\mathrm{k}$ promyvnym vodam [Physicochemical method of accelerating hard rock drilling using additives, hardness reducers to wash water]. Mining Journal, 1938, no.8-9, p.16.

5. Rebinder P.A., Shreiner L.A., Zhigach K.F. Primenenie ponizitelei tverdosti dlia povysheniia skorostei bureniia na neft $\mathrm{v}$ tverdykh porodakh vostochnykh mestorozhdenii [The use of hardness reducers to increase oil drilling speeds in East Rocks]. Neftianaia promyshlennost SSSR, 1940, no.5, p.54.

6. Rebinder P.A., Shchukin E.D. Poverkhnostnye iavleniia $\mathrm{v}$ tverdykh telakh $\mathrm{v}$ protsessakh 
ikh deformatsii i razrusheniia [Surface phenomena in solids in the processes of their deformation and destruction]. Uspekhi fizicheskikh nauk, 1972, vol.108, iss.1, pp.3-42.

7. Najmud D., Hayatdavoudi A., Ghalambor A. Laboratory investigation of saturation effect on mechanical properties of rocks. SPWLA $31^{\text {st }}$ Annual Logging Symposium, June 24-27, 1990, pp.1-23.

8. Mikhailov N.N., Popov S.N. Eksperimentalnye i teoreticheskie issledovaniia vliianiia mekhanokhimicheskikh effektov na filtratsionno-emkostnye, uprugie i prochnostnye svoistva porod-kollektorov [Experimental and theoretical studies of the influence of mechanochemical effects on the filtration-capacitive, elastic and strength properties of reservoir rocks]. Georesursy, geoenergetika, geopolitika, 2015, no. 1 (11), available at: http://oilgasjournal.ru/vol_11/popov.html (accessed 10 July 2019).

9. Gladkov P.D., Rogachev M.K. Issledovanie vliianiia gidrofobiziruiushchikh sostavov na mekhanicheskuiu prochnost obraztsov polimiktovykh peschanikov [Investigation of the effect of hydrophobizing compounds on the mechanical strength of polymict sandstones]. Neftegazovoe delo, 2012, no.1, pp.360-366.

10. Evseev V.D. O vozmozhnosti ispolzovaniia effekta P.A. Rebindera pri burenii skvazhin [On the possibility of using the effect of P.A. Rebinder when drilling wells]. Izvestiia Tomskogo politekhnicheskogo universiteta, 2010, vol.317, no.1, pp.165-169.

11. Evseev V.D. Priroda effekta Rebindera pri razrushenii gornykh porod [The nature of the Rehbinder's effect at rocks destruction]. Oil industry, 2011, no.11, pp.38-40.

12. Karmanskii A.T. Eksperimentalnoe obosnovanie prochnosti i razrusheniia nasyshchennykh osadochnykh gornykh porod [Experimental substantiation of the strength and fracture of saturated sedimentary rocks]. Abstract of Doctor's degree dissertation. Saint Petersburg, 2010, 37 p.

13. Karmanskii A.T., Stavrogin A.N. Vliianie vlazhnosti, vida napriazhennogo sostoianiia i skorosti razrusheniia na fiziko-mekhanicheskie svoistva gornykh porod [Influence of humidity, type of stress state and rate of destruction on physical and mechanical properties of rocks]. FTPRPI, 1992, no.4, pp.3-10.

14. Igdavletova M., Ismagilov T., Ganiev I., Telin A. Vliianie geologo-fizicheskikh kharakteristik produktivnykh plastov i svoistv plastovykh fliuidov na vybor vytesniaiushchego agenta pri zavodnenii [The influence of the geological and physical characteristics of reservoirs and the properties of reservoir fluids on the choice of a displacing agent during flooding]. Neftegaz.ru, 2014, no.7-8, pp.18-25.

15. Vásárhelyi B., Ván P. Influence of water content on the strength of rock. Engineering Geology, 2006, vol.84, no.1-2, pp.70-74.

16. Zhao B. et al. The effects of longterm waterflooding on the physical and mechanical properties of tight sandstones. 52nd US Rock Mechanics/Geomechanics Symposium. American Rock Mechanics Association, 2018, available at: https://www.onepetro. org/conference-paper/ARMA-2018-409?sort=\&start= $0 \& q=$ The + effects + of + long-term + waterflooding + on + the + physical + and + mechanical + proper-ties + of + tight + sandstones $+\&$ from year $=\&$ peer_reviewed $=\&$ published_between $=\&$ fromSearchResults $=$ true \&to_year $=\&$ rows $=25 \#$ (accessed 10 July 2019).

17. Glushchenko V.N., Silin M.A. Obemnye i poverkhnostno-aktivnye svoistva zhidkostei [Volumetric and surface-active properties of liquids]. Neftepromyslovaia khimiia. Moscow, Interkontakt Nauka, 2010, vol.2, $549 \mathrm{p}$

18. Deliia S.V. Abukova L.A., Abramova O.P., Anisimov L.A., Popov S.N., Vorontsova I.V. Eksperimentalnoe i chislennoe modelirovanie vzaimodeistviia plastovykh i tekhnicheskikh vod pri razrabotke mestorozhdeniia im. Iu. Korchagina [Experimental and numerical modeling of the interaction of formation and industrial waters during the development of the field named after Y. Korchagin]. Geologiia, geofizika $i$ razrabotka neftianykh $i$ gazovykh mestorozhdenii, 2012, no.10, pp.34-41. 
19. Nikolaevskii V.N., Basniev K.S., Gorbunov A.T. Mekhanika nasyshchennykh poristykh sred [Mechanics of saturated porous media]. Moscow, Nedra, 1970, 339 p.

20. Bishop A.W. The influence of an undrained change in stress on the pore pressure in porous media of low compressibility. Geotechnique, 1973, vol.23, no.3, pp.435-442.

21. Dake L.P. Fundamentals of reservoir engineering. Elsevier, 1983, vol.8, 492 p.

22. Fischer G.J. The determination of permeability and storage capacity: Pore pressure oscillation method. International Geophysics. Academic Press, 1992, vol.51, pp.187-211.

23. Lin S., Lai B. Experimental investigation of water saturation effects on Barnett Shale's geomechanical behaviors. Society of Petroleum Engineers, 2013. DOI: 10.2118/166234-MS

24. Liu K. et al. Predicting reservoir rock mechanical properties directly from sedimentary characterisation. SPE Asia Pacific Oil \& Gas Conference and Exhibition. Society of Petroleum Engineers, 2016, available at: https://www.onepetro. org/conference-paper/SPE-182342-MS (accessed 10 July 2019).

25. Adenutsi C.D. et al. Pore pressure variation at constant confining stress on water - oil and silica nanofluid - oil relative permeability. Journal of Petroleum Exploration and Production Technology, 2018, pp.1-15.

26. Alam M.M. et al. Effective stress coefficient for uniaxial strain condition. $46^{\text {th }} U S$ Rock Mechanics/Geomechanics Symposium. American Rock Mechanics Association, 2012, available at: https://www.onepetro.org/conferencepaper/ARMA-2012-302? sort $=\&$ start $=0 \& q=$ Effective + stress + coefficient + for+uniaxial + strain + condition $+\&$ from_year $=\&$ peer_reviewed $=\&$ published between $=\&$ fromSe-archResults $=$ true $\&$ to $\_$year $=\&$ rows $=25 \#$ (accessed 10 July 2019).

27. Wang H.F. Theory of linear poroelasticity with applications to geomechanics and hydrogeology. Princeton University Press, 2017, pp.26-49.

28. Nur A., Byerlee J.D. An exact effective stress law for elastic deformation of rock with fluids. Journal of Geophysical Research, 1971, vol.76, no.26, pp.6414-6419.
29. Skempton A.W. Effective stress in soils, concrete and rocks-pore pressure and suction in solis. Conference of the British National Society, London, 1961, pp.4-16.

30. Terzaghi K. Theoretical soil mechanics. London, Chapman And Hall, Limited, 1951, pp.123-130.

31. Zimmerman R.W., Somerton W.H., King M.S. Compressibility of porous rocks. Journal of Geophysical Research: Solid Earth, 1986, vol.91, no.B12, pp.12765-12777.

32. Fjar E., Holt R.M., Horsrud P. et al. Petroleum related rock mechanics. 2nd ed. Elsevier, 2008, vol. 53, 492 p.

33. Nermoen A., Korsnes R., Christensen H., Trads N., Hiorth A., Madland M.V. Measuring the Biot stress coefficient and its implications on the effective stress estimate. 47th US Rock Mechanics. Geomechanics Symposium, 2013, vol.1, available at: https://www.onepetro.org/ conference-paper/ARMA-2013-282?sort=\&start= $0 \& \mathrm{q}=$ Measuring + the + biot + stress + coefficient + and + is + implications + on + the + effective + stress + estimate $+\&$ from $\_$year $=\&$ peer_reviewed $=\&$ published_between $=\&$ fromSearchResults $=$ true $\&$ to $\_$year $=\&$ rows $=25 \#$ (accessed 10 July 2019).

34. Jun He, Zhenhua Rui, Kegang Ling. A new method to determine Biot's coefficients of Bakken samples. Journal of Natural Gas Science and Engineering, 2016, vol.35, part A, pp.259-264.

35. Biot M.A. General theory of threedimensional consolidation. Journal of Applied Physics, 1941, vol.12, no.2, pp.155-164.

36. Bailin W. et al. Boit's effective stress coefficient evaluation: static and dynamic approaches. ISRM International Symposium2nd Asian Rock Mechanics Symposium. International Society for Rock Mechanics and Rock Engineering. 2001, pp.369-372.

37. Franquet J.A. et al. Experimental evaluation of Biot's poroelastic parameter - three different methods. Rock Mechanics for Industry, 1999, pp.349-355.

38. King M.S., Marsden J.R., Dennis J.W. Biot dispersion for P-and S-wave velocities in partially and fully saturated sandstones. 
Geophysical Prospecting, 2000, vol. 48, no.6, pp.1075-1089.

39. Qiao L.P. et al. Determination of Biot's effective-stress coefficient for permeability of Nikanassin sandstone. Journal of Canadian Petroleum Technology, 2012, vol.51, no.03, pp.193-197.

40. Sahay P.N. Biot constitutive relation and porosity perturbation equation. Geophysics, 2013, vol.78, no.5, pp.L57-L67.

41. Müller T.M., Sahay P.N. Skempton coefficient and its relation to the Biot bulk coefficient and micro-inhomogeneity parameter. SEG Technical Program Expanded Abstracts 2014. Society of Exploration Geophysicists, 2014, pp.2905-2909.

42. Zhou X. et al. A combined method to measure Biot's coefficient for rock. 49th US Rock Mechanics/Geomechanics Symposium. American Rock Mechanics Association, 2015, available at: https://www.onepetro.org/conference-paper/ ARMA-2015-584? sort $=\&$ start $=0 \& \mathrm{q}=\mathrm{A}+$ combined + method + to + measure + biot $\%$ E $2 \% 80 \% 99$ s + coeffic ient + for + rock \&from_year $=\&$ peer_reviewed $=\& p u$ blished_between $=\&$ fromSearchResults $=$ true \& to year $=\&$ rows $=25 \#$ (accessed 10 July 2019).

43. Zhou X. et al. Biot's effective stress coefficient of mudstone source rocks. 51st US Rock Mechanics/Geomechanics Symposium. American Rock Mechanics Association, 2017, available at: https://www.onepetro.org/conference-paper/ ARMA-2017-0235 sort $=\&$ start $=0 \& q=$ Biot $\% E 2 \%$ $80 \% 99 \mathrm{~s}+$ effective + stress + coefficient + of + mudstone + source + rocks $+\% 2 \mathrm{~F}+\mathrm{Zhou}+\mathrm{X} .+\% 5 \mathrm{Bet}+\mathrm{al} \&$ from year $=\&$ peer_reviewed $=\&$ published_between $=\&$ fro$\mathrm{mSearchResults}=$ true $\&$ to $\_$year $=\&$ rows $=25 \# \quad($ accessed 10 July 2019).
44. Karmanskiy D., Maltsev A. Theoretical and experimental evaluation of formation fluid composition influence on filtration and elastic properties of porous media. Physical and mathematical modeling of Earth and environment processes. Eds. V. Karev, D. Klimov, K. Pokazeev. Springer, Springer Geology, Cham, 2017, pp.84-89.

45. Penkov G.M., Karmansky D.A., Petrakov D.G. Simulation of a fluid influx in complex reservoirs of Western Siberia. Topical Issues of Rational Use of Natural Resources: Proceedings of the International Forum-Contest of Young Researchers. Saint Petersburg, 2018, pp.119-124.

46. Bieniawski Z.T., Bernede M.J. Suggested methods for determining the uniaxial compressive strength and deformability of rock materials: Part 1. Suggested method for determining deformability of rock materials in uniaxial compression. International Journal of Rock Mechanics and Mining Sciences \& Geomechanics Abstracts, 1979, vol.16, iss.2, pp.138-140.

47. Sato M., Takemura T., Takahashi M. Development of the permeability anisotropy of submarine sedimentary rocks under true triaxial stresses. International Journal of Rock Mechanics and Mining Sciences, 2018, vol.108, pp.118-127.

48. $\mathrm{Yu} \mathrm{J}$. et al. Triaxial test research on mechanical properties and permeability of sandstone with a single joint filled with gypsum. KSCE Journal of Civil Engineering, 2016, vol.20, no.6, pp.2243-2252.

49. Suggested methods for determining the strength of rock materials in triaxial compression: Revised version. International Journal of Rock Mechanics and Mining Sciences \& Geomechanics Abstracts, 1983, vol.20, iss.6, pp.285-290.

\section{Библиографический список}

1. Колчицкая Т.Н., Михайлов Н.Н. Влияние циклических режимов эксплуатации скважин на изменение состояния нефтегазовых пластов // Геология, геофизика и разработка нефтяных и газовых месторождений. - 2002. - № 5. C. $78-81$.

2. Влияние свойств горных пород на движение в них жидкости / А. Бан [и др.]. М.: Гостоптехиздат, 1962. - С. 158-187.
3. Ребиндер П.А. Поверхностные явления в дисперсных системах. Физико-химическая механика // Избранные труды. - М.: Наука, 1979. - 384 c.

4. Ребиндер П.А., Шрейнер Л.А. Физикохимический метод ускорения бурения твердых пород c помощью добавок, понизителей твердости к промывным водам // Горный журнал. - 1938. - № 8-9. - С. 16. 
5. Ребиндер П.А., Шрейнер Л.А., Жигач К.Ф. Применение понизителей твердости для повышения скоростей бурения на нефть в твердых породах Восточных месторождений // Нефтяная промышленность СССР. - 1940. № $5 .-$ С. 54 .

6. Ребиндер П.А., Щукин Е.Д. Поверхностные явления в твердых телах в процесcax их деформации и разрушения // Успехи физических наук. - 1972. - Т. 108, вып. 1. - С. 3-42.

7. Najmud D., Hayatdavoudi A., Ghalambor A. Laboratory investigation of saturation effect on mechanical properties of rocks // SPWLA $31^{\text {st }}$ Annual Logging Symposium. - 1990. P. 1-23.

8. Михайлов Н.Н., Попов С.Н. Экспериментальные и теоретические исследования влияния механохимических эффектов на фильтрационно-емкостные, упругие и прочностные свойства пород-коллекторов [Электронный ресурс] // Георесурсы, геоэнергетика, геополитика. - 2015. - № 1 (11). URL: http://oilgasjournal.ru/vol_11/popov.html (дата обращения: 10.07.2019).

9. Гладков П.Д., Рогачев М.К. Исследование влияния гидрофобизирующих составов на механическую прочность образцов полимиктовых песчаников // Нефтегазовое дело. 2012. - № 1. - Р. 360-366.

10. Евсеев В.Д. О возможности использования эффекта П.А. Ребиндера при бурении скважин // Известия Томского политехнического университета. - 2010. Т. 317, № 1. - С. 165-169.

11. Евсеев В.Д. Природа эффекта Ребиндера при разрушении горных пород // Нефтяное хозяйство. -2011 . - № 11. - С. 38-40.

12. Карманский А.Т. Экспериментальное обоснование прочности и разрушения насыщенных осадочных горных пород: автореф. дис. ... д-ра техн. наук. - СПб., 2010. - 37 c.

13. Карманский А.Т., Ставрогин А.Н. Влияние влажности, вида напряженного состояния и скорости разрушения на физикомеханические свойства горных пород // ФТПРПИ. - 1992. - № 4. - С. 3-10.
14. Влияние геолого-физических характеристик продуктивных пластов и свойств пластовых флюидов на выбор вытесняющего агента при заводнении / М. Игдавлетова, Т. Исмагилов, И. Ганиев, А. Телин // Neftegaz.ru. - 2014. - № 7-8. - C. 18-25.

15. Vásárhelyi B., Ván P. Influence of water content on the strength of rock // Engineering Geology. - 2006. - Vol. 84, № 1-2. P. 70-74.

16. The effects of long-term waterflooding on the physical and mechanical properties of tight sandstones [Электронный pecypc] / B. Zhao [et al.] // 52nd US Rock Mechanics/Geomechanics Symposium. - American Rock Mechanics Association, 2018. - URL: https://www.onepetro. org/conference-paper/ARMA-2018-409? sort=\&start= $0 \& \mathrm{q}=$ The + effects + of + long-term + waterflooding + on + the + physical + and + mechanical + proper-ties + of + tight + sandstones $+\&$ from_year $=\&$ peer_reviewed $=\&$ published_between $=\&$ fromSearchResults $=$ true \&to_year=\&rows=25\# (дата обращения: 10.07.2019).

17. Глущенко В.Н., Силин М.А. Объемные и поверхностно-активные свойства жидкостей // Нефтепромысловая химия. - М.: Интерконтакт Наука, 2010. - Т. 2. - 549 с.

18. Экспериментальное и численное моделирование взаимодействия пластовых и технических вод при разработке месторождения им. Ю. Корчагина / С.В. Делия, Л.А. Абукова, О.П. Абрамова, Л.А. Анисимов, С.Н. Попов, И.В. Воронцова // Геология, геофизика и разработка нефтяных и газовых месторождений. - 2012. - № 10. - С. 34-41.

19. Николаевский В.Н., Басниев К.С., Горбунов А.T. Механика насыщенных пористых сред. - М.: Недра, 1970. - 339 с.

20. Bishop A.W. The influence of an undrained change in stress on the pore pressure in porous media of low compressibility // Geotechnique. - 1973. - T. 23, № 3. P. 435-442.

21. Dake L.P. Fundamentals of reservoir engineering. - Elsevier, 1983. - Vol. 8. - 492 p.

22. Fischer G.J. The determination of permeability and storage capacity: Pore pressure oscillation method // International Geophysics. Academic Press, 1992. - Vol. 51. - P. 187-211. 
23. Lin S., Lai B. Experimental investigation of water saturation effects on Barnett Shale's geomechanical behaviors / Society of Petroleum Engineers. - 2013. DOI: $10.2118 / 166234-\mathrm{MS}$

24. Predicting reservoir rock mechanical properties directly from sedimentary characterisation [Электронный ресурс] / K. Liu [et al.] // SPE Asia Pacific Oil \& Gas Conference and Exhibition / Society of Petroleum Engineers. 2016. - URL: https://www.onepetro.org/conferencepaper/SPE-182342-MS (дата обращения: 10.07.2019).

25. Pore pressure variation at constant confining stress on water - oil and silica nanofluid oil relative permeability / C.D. Adenutsi [et al.] // Journal of Petroleum Exploration and Production Technology. - 2018. - № 9. - P. 1-15.

26. Effective stress coefficient for uniaxial strain condition [Электронный pecypc] / M.M. Alam [et al.] // 46th US Rock Mechanics/Geomechanics Symposium / American Rock Mechanics Association, 2012. URL: https://www.onepetro.org/conference-paper/ ARMA-2012-302? sort $=\&$ start $=0 \& \mathrm{q}=$ Effective + stress + coefficient + for + uniaxial + strain + condition $+\&$ from_year $=$ \&peer_reviewed $=\&$ published_between $=$ $\&$ fromSe-archResults $=$ true \& to year $=\&$ rows $=25 \#$ (дата обращения: 10.07.2019).

27. Wang H.F. Theory of linear poroelasticity with applications to geomechanics and hydrogeology. - Princeton University Press, 2017. - P. 26-49.

28. Nur A., Byerlee J.D. An exact effective stress law for elastic deformation of rock with fluids // Journal of Geophysical Research. 1971. - Vol. 76, № 26. - P. 6414-6419.

29. Skempton A.W. Effective stress in soils, concrete and rocks-Pore pressure and suction in solis // Conference of the British National Society. - London, 1961. - P. 4-16.

30. Terzaghi K. Theoretical soil mechanics. London: Chapman And Hall, Limited, 1951. P. 123-130.

31. Zimmerman R.W., Somerton W.H., King M.S. Compressibility of porous rocks // Journal of Geophysical Research: Solid Earth. - 1986. Vol. 91, № B12. - P. 12765-12777.
32. Petroleum related rock mechanics / E. Fjar, R.M. Holt, P. Horsrud [et al.]. - 2nd ed. - Elsevier, 2008. - Vol. 53. - 492 p.

33. Measuring the Biot stress coefficient and its implications on the effective stress estimate [Электронный ресурс] / A. Nermoen, R. Korsnes, H. Christensen, N. Trads, A. Hiorth, M.V. Madland // 47th US Rock Mechanics. Geomechanics Symposium. - 2013. URL: https://www.onepetro.org/conference-paper/ ARMA-2013-282? sort $=\&$ start $=0$ \&q=Measuring + the + biot + stress + coefficient + and + is + implications + on + the + effective + stress + estimate $+\&$ from $\_$year $=\&$ peer_reviewed $=\&$ published_between $=\&$ fromSearch Results $=$ true\&to_year $=\&$ rows $=25 \#$ (дата обращения: 10.07.2019).

34. Jun He, Zhenhua Rui, Kegang Ling. A new method to determine Biot's coefficients of Bakken samples // Journal of Natural Gas Science and Engineering. - 2016. - Vol. 35, part A. - P. 259-264.

35. Biot M.A. General theory of threedimensional consolidation // Journal of Applied Physics. - 1941. - Vol. 12, № 2. - P. 155-164.

36. Biot's effective stress coefficient evaluation: static and dynamic approaches / W. Bailin [et al.] // ISRM International Symposium-2nd Asian Rock Mechanics Symposium / International Society for Rock Mechanics and Rock Engineering. - Beijing, 2001. - P. 369-372.

37. Experimental evaluation of Biot's poroelastic parameter - Three different methods / J.A. Franquet [et al.] // Rock Mechanics for Industry. - 1999. - P. 349-355.

38. King M.S., Marsden J.R., Dennis J.W. Biot dispersion for $\mathrm{P}$-and $\mathrm{S}$-wave velocities in partially and fully saturated sandstones // Geophysical Prospecting. - 2000. - Vol. 48, № 6. - P. 1075-1089.

39. Determination of Biot's effective-stress coefficient for permeability of Nikanassin sandstone / L.P. Qiao [et al.] // Journal of Canadian Petroleum Technology. - 2012. Vol. 51, № 03. - P. 193-197.

40. Sahay P.N. Biot constitutive relation and porosity perturbation equation // Geophysics. 2013. - Vol. 78, № 5. - P. L57-L67. 
41. Müller T.M., Sahay P.N. Skempton coefficient and its relation to the Biot bulk coefficient and micro-inhomogeneity parameter // SEG Technical Program Expanded Abstracts 2014 / Society of Exploration Geophysicists, 2014. - P. 2905-2909.

42. A combined method to measure Biot's coefficient for rock [Электронный pecypc] / X. Zhou [et al.] // 49th US Rock Mechanics/ Geomechanics Symposium / American Rock Mechanics Association, 2015. - URL: https://www.onepetro.org/ conference-paper/ARMA-2015-584? sort=\&start= $0 \& \mathrm{q}=\mathrm{A}+$ combined + method + to + measure + biot $\% \mathrm{E}$ $2 \% 80 \% 99 \mathrm{~s}+$ coefficient + for + rock $\&$ from $\_$year $=\&$ peer reviewed $=\&$ published between $=\&$ fromSearch Results $=$ true\&to_year=\&rows=25\# (дата обращения: 10.07.2019).

43. Biot's effective stress coefficient of mudstone source rocks [Электронный pecypc] / X. Zhou [et al.]// 51st US Rock Mechanics/ Geomechanics Symposium / American Rock Mechanics As strain condition sociation. - San Francisco, 2017. - URL: https://www.onepetro.org/ conference-paper/ARMA-2017-0235?sort=\&start= $0 \& \mathrm{q}=$ Biot $\% \mathrm{E} 2 \% 80 \% 99 \mathrm{~s}+$ effective + stress + coeffici ent + of + mudstone + source + rocks $+\% 2 F+Z$ hou $+\mathrm{X} .+$ $\% 5$ Bet + al \&from_year $=\&$ peer_reviewed $=\&$ publish ed between $=\&$ fromSearchResults $=$ true $\&$ to year $=$ \&rows=25\# (дата обращения: 10.07.2019).

44. Karmanskiy D., Maltsev A. Theoretical and experimental evaluation of formation fluid composition influence on filtration and elastic properties of porous media // Physical and mathematical modeling of Earth and environment processses / eds. V. Karev, D. Klimov, K. Pokazeev. - Springer, Cham, 2017. - P. 84-89.

45. Penkov G.M., Karmansky D.A., Petrakov D.G. Simulation of a fluid influx in complex reservoirs of Western Siberia // Topical Issues of Rational Use of Natural Resources: Proceedings of the International ForumContest of Young Researchers. St. Petersburg, 2018. - P. 119-124.

46. Bieniawski Z.T., Bernede M.J. Suggested methods for determining the uniaxial compressive strength and deformability of rock materials: Part 1. Suggested method for determining deformability of rock materials in uniaxial compression // International Journal of Rock Mechanics and Mining Sciences \& Geomechanics Abstracts. - 1979. - Vol. 16, iss. 2. - P. $138-140$.

47. Sato M., Takemura T., Takahashi M. Development of the permeability anisotropy of submarine sedimentary rocks under true triaxial stresses // International Journal of Rock Mechanics and Mining Sciences. - 2018. Vol. 108. - P. 118-127.

48. Triaxial test research on mechanical properties and permeability of sandstone with a single joint filled with gypsum / J. Yu [et al.] // KSCE Journal of Civil Engineering. - 2016. Vol. 20, № 6. - P. 2243-2252.

49. Suggested methods for determining the strength of rock materials in triaxial compression: Revised version // International Journal of Rock Mechanics and Mining Sciences \& Geomechanics Abstracts. - 1983. - Vol. 20, iss. 6. - P. 285-290.

Please cite this article in English as:

Karmanskiy D.A., Petrakov D.G. Laboratory simulation of change in mechanical and flow properties of reservoir formations at various stages of oil-field development. Perm Journal of Petroleum and Mining Engineering, 2020, vol.20, no.1, pp.49-59. DOI: $10.15593 / 2224-9923 / 2020.1 .5$

Просьба ссылаться на эту статью в русскоязычных источниках следующим образом:

Карманский Д.А., Петраков Д.Г. Лабораторное моделирование изменения механических и фильтрационных свойств пород коллекторов на различных этапах разработки месторождений нефти // Вестник Пермского национального исследовательского политехнического университета. Геология. Нефтегазовое и горное дело. - 2020. - Т.20, №1. C.49-59. DOI: $10.15593 / 2224-9923 / 2020.1 .5$ 